\title{
The professionalisation of Irish medicine in the generations before Charles Lucas
}

\author{
M. A. Lyons
}

Received: 19 September 2014/Accepted: 19 November 2014/Published online: 14 March 2015

(C) Royal Academy of Medicine in Ireland 2015

\begin{abstract}
The educational opportunities and qualifications, corporate structures and regulation that had become accepted features of the Irish medical profession in the era of Charles Lucas were the fruits of a slow process of professionalization initiated by a handful of Irish medics who, from the $1620 \mathrm{~s}$, began tackling poor standards of medical practice in an era of medical pluralism. This paper begins by reviewing the standard of practice in early seventeenth-century Ireland. Through the examples of Thomas Arthur, M.D. and John Clavell, a self-styled medic, differences in the approaches adopted by university-trained physicians and unorthodox practitioners are highlighted. The succession of significant steps taken in this professionalization process are traced, with particular emphasis on the failed attempt to establish a Royal College of Physicians in Dublin during the mid-1620s and the importance of the influx of English physicians in the 1650s for the creation of permanent corporate structures and regulation.
\end{abstract}

Keywords Medical profession in Ireland - Thomas

Arthur - Medical education - Unlicensed medical practitioners

In publishing his pamphlet Pharmacomastix (Dublin, 1741) about inappropriate sale of drugs; in lobbying Parliament to legislate for tighter regulation of drug administration; in pursuing his education as a physician at Paris, Reims and Leiden; and in having the option of being affiliated to the London and Dublin Colleges of Physicians, Charles Lucas demonstrated how far the professionalisation of medical

M. A. Lyons ( $\square)$

Department of History, Rhetoric House, Maynooth University,

Maynooth, Co. Kildare, Ireland

e-mail: Marian.Lyons@nuim.ie practice in Ireland had come since its halting beginnings in the early seventeenth century. For Lucas, it was easy to use the print media to highlight abuses within the medical profession. In going to Paris, Reims and Leiden, he joined hundreds of Irishmen who pursued their medical studies in those universities. Whilst practicing as a physician in London, it was a matter of course that Lucas would become a member of that city's College of Physicians, and it was his intention to join the Dublin College had other commitments not prevented this [1].

However, when contemplating Charles Lucas's contribution to medicine in Ireland we should be mindful that all of these services, educational opportunities and formal corporate structures that were readily at the disposal of élite medical practitioners in the eighteenth century had their genesis in the initiatives of a handful of Irish medics who began the slow process of professionalising and regulating medical practice in the country over a century before.

The 1610s witnessed a significant departure in medical practice in Ireland as four young Catholic men, Gerald Fennell, Dermot O'Meara, Christopher Talbot and Thomas Arthur, all graduates of the Faculty of Reims in north western France, returned home and embarked on careers as physicians. From then, Reims Faculty of Medicine had a formative impact on the professionalisation of medical provision in Ireland because, unlike the more prestigious Faculty at Leiden, which was frequented mainly by Protestants, Reims afforded Irish Catholics of modest means the opportunity to pursue a course of study which was widely acknowledged to be less challenging academically than at Leiden, and at a fraction of the cost [2].

That these graduates returned home to practice, apparently without impediment from any authority, testifies to the growing confidence and expectations among middleranking Catholics in Jacobean Ireland. They embarked on 
their careers in an era of 'medical pluralism' in which professionally trained healers including physicians, barbersurgeons and apothecaries and non-professionals-quacks, wise women and charlatans-operated coterminously in the absence of corporate regulation. For them, there was no Irish equivalent of the London College of Physicians to which they could become affiliated. In fact, in 1619 there was only one medical corporation in Ireland-the BarberSurgeons' Guild in Dublin, founded in 1446 [3].

In such a milieu, it is hardly surprising to find that standards of health care were alarmingly low. In his Pathologia Hereditaria Generalis (Dublin, 1619) Dr Dermot O'Meara denounced the lack of regulation which gave amateurs 'free leave to profane the holy temple of Esculapius'. The appearance of this first medical text printed in Ireland signaled both the arrival of a new breed of graduate physician and their recourse to the print media in the drive to professionalise Irish medicine.

Thomas Arthur shared O'Meara's outrage, seeing for himself the damage inflicted on victims of botched treatments administered by incompetent practitioners. Their impatience at the lack of corporate regulation and structures was shared by a handful of physicians connected with the Dublin government. In 1626, it looked as if a Royal College of Physicians might be established in Dublin. O'Meara, Christopher Talbot, and John Verdon joined two physicians attached to Dublin Castle, James Metcalfe and Paul Delaune, in a campaign to secure royal approval for such a foundation. Initially, Charles I seemed positively disposed. However, this proved a false dawn as a sudden shift in international politics, combined with the equally sudden recall of two key supporters of the initiative to England, resulted in the plan being shelved until the late 1660s. In the interim, the Irish medical marketplace was left to continue operating in a highly unregulated state.

Although they regarded themselves as the top of the pile, physicians had to fend off competition from opportunistic rival, unlicensed and unqualified practitioners such as John Clavell, an English-born highwayman turned author, lawyer and self-styled physician who, although unlicensed, practiced extensively in both Cork and Dublin during the 1630s. Arthur's practice contrasted with those of unlicensed medics. Having begun his career in Limerick in 1619, he moved to Dublin during the mid-1620s, quickly establishing a reputation for excellence and a highly lucrative practice after he successfully treated Archbishop James Ussher. Whereas Arthur tended to be sought out by patients from as far away as Antrim, unlicensed practitioners such as Clavell travelled around, actively soliciting business. Clavell even poached one of Arthur's prominent patients, the Lord Chancellor Adam Loftus.
The distinction is also apparent in diagnosis and treatment of patients. Arthur's university training was evident in his scientific and pastoral approach to both: some of his treatments took years [4]. By contrast, Clavell promised his potential patients quick and complete cures: not surprisingly he saw far greater numbers. Nevertheless, while Clavell may have typified the rogue unlicensed practitioners criticized by O'Meara in his 1619 publication, his career demonstrates that at least some amateurs had sufficient command of the science of medicine to convince even senior officials in the Dublin administration of their competence.

The absence of corporate regulation proved advantageous in certain respects for Catholic physicians such as Arthur and Fennell. Owing to their small number and established reputations as expert practitioners in both Catholic and Protestant circles, they were generally left to get on with their practices, unimpeded by government or other authority. However, that changed as a result of the Confederate and Cromwellian wars (1640s and 1650s) which brought an influx of English physicians, apothecaries and surgeons to Ireland, the most important being Abraham Yarner and Sir William Petty. Consequently, for the first time, in the early 1650s Dublin had a critical mass of physicians, some with ties to the Royal College of Physicians in London. Yarner, who later became president of the College of Physicians in Dublin, was a pivotal figure in generating an esprit de corps among physicians in the city, holding banquets and philosophical gatherings to which he invited Catholic physicians, including Arthur and Fennell.

Within a few years, the Professor of Medicine at Trinity College, John Sterne gave that professional fraternalism corporate expression by establishing the Fraternity of Physicians in Trinity Hall in 1654: this, in turn, evolved into the Royal College of Physicians in 1667. Both developments set the professionalisation of Irish medicine on a new plain. Under the new regulated regime, TCD conferred medical degrees and the Royal College of Physicians granted licenses to graduates. The informal fraternalism of Arthur's day gave way to a stricter regime which required applicants to take oaths and, in the process, delineated between Protestants and Catholics [5].

The incorporation of the Royal College of Physicians and TCD made significant strides towards introducing the long overdue regulatory structures, procedures, and standards that were in place when Charles Lucas began his career as an apothecary in Dublin. Yet, vestiges of the medical pluralism that had for so long characterized the sector in Ireland endured. As Lucas's publication of Pharmacomastix testifies, even in the 1740 s much remained to be done in terms of the regulation of medicine in Ireland. 


\section{References}

1. Kelly J (2009) Charles Lucas. In: McGuire J, Quinn J (eds) Dictionary of Irish Biography. Cambridge University Press, Cambridge

2. Graduate Register of the old Faculté de Médecine de Reims. Bibliothèque Municipale, Reims, MS 1085

3. Kelly J (1999) The emergence of scientific and institutional medical practice in Ireland, 1650-1800. In: Jones G, Malcolm E (eds) Medicine, disease and the state in Ireland, 1650-1940. Cork University Press, Cork, pp 21-22

4. Thomas Arthur (1593-1666?) M.D. of Limerick miscellaneous entry-book. British Library, Additional MS 31885

5. Lyons MA (2010) The role of graduate physicians in professionalising medical practice in Ireland, c.1619-54. In: Kelly J, Clark F (eds) Ireland and medicine in the seventeenth and eighteenth centuries. Ashgate Publishing, Farnham, pp 17-37 